\title{
Induced Methylation in Plants as a Crop Improvement Tool: Progress and Perspectives
}

\author{
Clémentine Mercé, Philipp E. Bayer, Cassandria Tay Fernandez, Jacqueline Batley(i) \\ and David Edwards * (D)
}

Applied Bioinformatics Group, School of Biological Sciences, The University of Western Australia, Perth, WA 6009, Australia; clementine.merce@research.uwa.edu.au (C.M.); philipp.bayer@uwa.edu.au (P.E.B.); cassandria.tayfernandez@research.uwa.edu.au (C.T.F.); jacqueline.batley@uwa.edu.au (J.B.)

* Correspondence: dave.edwards@uwa.edu.au

Received: 6 July 2020; Accepted: 23 September 2020; Published: 28 September 2020

check for updates

\begin{abstract}
The methylation of gene promoters is an epigenetic process that can have a major impact on plant phenotypes through its control of gene expression. This phenomenon can be observed as a response to stress, such as drought, cold/heat stress or pathogen infection. The transgenerational heritability of DNA methylation marks could enable breeders to fix beneficial methylation patterns in crops over successive generations. These properties of DNA methylation, its impact on the phenotype and its heritability, could be used to support the accelerated breeding of improved crop varieties. Induced DNA methylation has the potential to complement the existing plant breeding process, supporting the introduction of desirable characteristics in crops within a single generation that persist in its progeny. Therefore, it is important to understand the underlying mechanisms involved in the regulation of gene expression through DNA methylation and to develop methods for precisely modulating methylation patterns for crop improvement. Here we describe the currently available epigenetic editing tools and their advantages and limitations in the domain of crop breeding. Finally, we discuss the biological and legislative limitations currently restricting the development of epigenetic modification as a crop improvement tool.
\end{abstract}

Keywords: induced DNA methylation; crop improvement; phenotype; heritability

\section{Introduction}

Traditional plant breeding involves repeated crossing and selection based on morphological traits, with molecular methods introduced in recent decades to complement phenotypic selection. Genome editing using tools such as the CRISPR-Cas9 system is still novel technology that is starting to be applied to make direct changes to the nucleotide sequence of crops. In addition to these genetic changes, an improved understanding of the effect of epigenetic variation such as DNA methylation on plant phenotype has provided an opportunity to further accelerate the crop improvement process. Therefore, epigenome editing could help overcome some weaknesses of genome editing (such as gene knockout), which can have a strong off-target impact and only enables the loss of function of a gene.

DNA methylation appears as a promising source of variation contributing to the fitness and yield of crops due to its heritability and ability to impact plant phenotypes. Agronomically important traits such as flowering time, seed dormancy and yield are influenced by DNA methylation variations, and the partial heritability of DNA methylation patterns suggests epigenetics has played a role in plant domestication and evolution [1-3]. Mastering DNA methylation modification will allow breeders to simultaneously induce beneficial variations and restrain undesirable epigenetic modifications that can be induced by breeding methods such as tissue culture [4-8]. Different methods have already been developed for this purpose and effective induction of epigenetic changes for plant breeding requires a 
technical understanding of the molecular processes involved in both its introduction and maintenance over subsequent generations. Here, we summarize recent technical advances in epigenome editing tools as well as the biological and legal limitations that have yet to be overcome.

\section{DNA Methylation in Plants}

Epigenetic modifications alter the DNA molecule, however, the DNA sequence itself remains unchanged. DNA methylation is the most common type of epigenetic modification, defined by the covalent addition of a methyl group $\left(\mathrm{CH}_{3}\right)$ to the fifth position of a cytosine ring $(5 \mathrm{mC})$ by DNA methyltransferases. DNA methylation is a heritable and reversible process, involved in multiple genetic and genomic cellular mechanisms such as transposon silencing, tissue-specific gene expression and genome balance after polyploidization [9-14].

DNA methylation is a complex process involving interactions between multiple genomic elements and is yet to be fully understood. DNA methylation in promoter regions has been known to play a major role in regulating gene expression since $1975[15,16]$. When covalently attached to DNA, methyl groups can block the access of the transcription machinery to the gene and reduce transcription. The correlation between promoter methylation and reduced gene expression is well-established; however, induced promoter methylation is not always sufficient to repress nearby gene expression [17]. For example, the methylation of the FWA promoter only induces a limited downregulation of the gene when located more than $500 \mathrm{bp}$ from the transcription start site [18].

While the role of gene promoter methylation is slowly being elucidated, the role of gene body methylation (gbM) remains largely unknown [19]. One hypothesis is that methylation is involved in gene splicing, as it has been noted that exons contain more DNA methylation compared to introns, and spliced exons are generally less methylated [20,21]. Moreover, it has been described that gbM is mainly found on constitutively expressed genes and is occasionally located on genes with fluctuating expression level [20] suggesting a relationship between gbM and transcription [22]. The mechanisms leading to specific methylation patterns are yet to be determined. Due to its potential regarding transcriptome regulation and phenotype modification, DNA methylation is of particular interest to plant breeding.

\subsection{Effect of DNA Methylation on Plant Phenotype}

Interest in the impact of epigenetic modifications on plant phenotypes has increased since 1999 following the observation of the first naturally occurring morphological mutant in the Lcyc gene of Linaria vulgaris not caused by DNA mutation [23], showing the existence of epi-allelic variants. The same study demonstrated that restoring the original methylation state recovered the wild-type phenotype. Since then, several studies have confirmed a link between DNA methylation modifications and disrupted phenotypes which influence many complex traits (Table 1). For example, a spontaneous epigenetic mutation at the $\mathrm{Cnr}$ locus can inhibit fruit ripening in tomato [24]. The comparison of plants diverging only by their methylome (i.e., epigenetic recombinant inbred lines) has shown the impact of hypomethylated genes on phenotypic alterations in traits such as flowering time [25]. The comparison of cultivated and wild cotton led to the identification of domestication traits influenced by epigenome evolution, such as flowering time and seed dormancy [1]. Observation of the impacted phenotypes confirms the idea that variation in methylation patterns is a way for plants to adapt to the environment $[2,26,27]$. 
Table 1. Examples of phenotypic traits sensitive to epigenetic modifications.

\begin{tabular}{|c|c|c|c|}
\hline Species & Phenotype & Gene & Reference \\
\hline Alternanthera philoxeroides & $\begin{array}{l}\text { Leaves and internode size, stem pith } \\
\text { cavity diameter }\end{array}$ & / & [27] \\
\hline Antirrhinum majus & $\begin{array}{l}\text { shade avoidance syndrome } \\
\text { (stem elongation) }\end{array}$ & / & [28] \\
\hline Arabidopsis thaliana & $\begin{array}{l}\text { flowering time, plant height, } \\
\text { total biomass, fruit number, root: } \\
\text { shoot ratio (drought tolerance) }\end{array}$ & / & [2] \\
\hline Arabidopsis thaliana & flowering time and plant height & $F W A$ & [25] \\
\hline Arabidopsis thaliana & $\begin{array}{l}\text { traits related to reproduction and } \\
\text { fecundity (day of bolting, number of } \\
\text { rosette leaves at bolting, number of } \\
\text { branches and number of siliques) }\end{array}$ & At2g06002 & [29] \\
\hline Cannabis sativa L. & Resistance to heavy metals & / & [30] \\
\hline Gossypium hirsutum & \multirow{2}{*}{ flowering time and seed dormancy } & \multirow{2}{*}{ COL2 } & \multirow{2}{*}{ [1] } \\
\hline Gossypium barbadense & & & \\
\hline Hevea brasiliensis & cold tolerance & HbICE1, HbCBF2, COR & [31] \\
\hline Linaria vulgaris & flower morphology & Lcyc & [23] \\
\hline $\begin{array}{l}\text { Mesembryanthemum } \\
\text { crystallinum }\end{array}$ & Adaptation to salt stress & / & [32] \\
\hline Nicotiana tabacum & hypersensitive response & NtAlix1 & [33] \\
\hline Nicotiana tabacum & hypersensitive response & $N t G P D L$ & [34] \\
\hline Solanum lycopersicum & fruit ripening & $\mathrm{Cnr}$ & [24] \\
\hline S. lycopersicum & vitamin $\mathrm{E}$ accumulation & VTE3 & [35] \\
\hline Zea mays & Response to cold stress & ZmMI1 & [36] \\
\hline Zea mays & yield & / & [37] \\
\hline
\end{tabular}

\subsection{Impact of the Environment on Plant DNA Methylation}

A recent study of $A$. thaliana estimated the spontaneous CG methylation gain at $2.56 \times 10^{-4}$ and methylation loss at $6.3 \times 10^{-4}$ [38]. However, environmental stress can impact both DNA methylation rate and profile in plants, as shown in $A$. thaliana lines under salt-stress that accumulated $\sim 45 \%$ more differentially methylated cytosines in a CG context, preferentially located in genic regions [26]. Similarly, a study in rice exposed to drought highlighted a non-random distribution of stress induced epimutations, many of them being in loci associated with drought resistance [39]. Other examples of environmental factors leading to altered gene expression have been demonstrated, including in A. thaliana under phosphate starvation, pathogen exposure, in rice exposed to cadmium, or under anoxia and drought stress [40-44]. Cold-induced gene demethylation led to an increase in transcriptional activity and seems to play an important role in Hevea brasiliensis cold tolerance [31]. However, as demonstrated with the stability of the methylome of a geographically dispersed $A$. thaliana population, changes in the environment are not always sufficient to trigger an epigenetic response [45]. Interestingly, the temporal hierarchy of transcriptome and epigenome changes under environmental stress remains ambiguous as stress-induced gene expression seems to drive the hypermethylation of adjacent transposable elements [46]. 


\subsection{DNA Methylation Heritability in Plants}

Unlike genomic variation, the ability of epigenetic markers to transmit acquired environmentally adaptive traits to offspring is highly advantageous. Several examples of DNA methylation pattern heritability have been described in different plant species, such as $A$. thaliana, Picea abies, Taraxacum officinale and Nicotiana tabacum and crop species, including: rice and wheat [47-52] (Table 2). In A. thaliana, DNA methylation variation transmission has been observed for at least eight generations [25]. Epigenetic changes induced by stress can be transmitted to offspring, but their stability and the potential effect on a population in the long term is unknown [49]. A recent study on epigenetic modifications occurring during the domestication of cotton concluded that epialleles were transmitted between generations, resulting in phenotypic diversity and allowing a large geographic expansion of the species [1]. Intergenerational transmission of phenotypic traits caused by DNA methylation variations, such as roots adapted to drought stress, delayed flowering time and modified plant architecture has also been demonstrated $[29,53]$. Since methylation is heritable and can cause phenotypic changes, inducing/removing DNA methylation has been a focus of research with the aim of remodeling the expression of genes already present in crop genomes. The growing interest in epigenomics has led to the development of methods to induce DNA methylation, first genome-wide with non-specific methods and now at a base-specific level with new epigenetic editing tools.

Table 2. Examples of DNA methylation transmission studies in plants.

\begin{tabular}{clcc}
\hline Species & \multicolumn{1}{c}{ Trait } & Generations & Reference \\
\hline Arabidopsis thaliana & adaptation to extreme temperature & 3 & [47] \\
\hline Arabidopsis thaliana & flowering time and plant height & 8 & [25] \\
\hline Arabidopsis thaliana & disease resistance & 3 & [54] \\
\hline Arabidopsis thaliana & flowering time and plant architecture & 3 & [29] \\
\hline Nicotiana tabacum & resistance to viral, bacterial, & 2 & [50] \\
\cline { 2 - 4 } Oryza sativa L. & $\begin{array}{l}\text { altered gene expression induced by } \\
\text { heavy metal stress }\end{array}$ & 2 & [55] \\
\hline Oryza sativa L. & tolerance to nitrogen-deficiency stress & 2 & [51] \\
\hline Oryza sativa ssp. japonica & $\begin{array}{l}\text { dwarfism, resistance to the bacteria X. } \\
\text { oryzae pv. oryzae }\end{array}$ & 9 & [56] \\
\hline Picea abies & $\begin{array}{l}\text { adaptation to photoperiod and } \\
\text { temperature }\end{array}$ & 1 & [48] \\
\hline Polygonum persicaria & drought stress tolerance & 1 & [53] \\
\hline Taraxacum officinale & $\begin{array}{l}\text { defence against pathogen and } \\
\text { chemical induction of herbivore }\end{array}$ & 2 & [49] \\
\hline Triticum aestivum L. & heat tolerance & 1 & [52] \\
\hline
\end{tabular}

\section{Induced (de)Methylation}

The primary techniques developed to study DNA methylation, such as demethylating agents and gene knock-out, cause changes to the epigenetic state at a non-specific, genome-wide scale. The resulting plant displays numerous phenotypic and developmental aberrancies [57], which cannot be linked to specific genes. Although these methods paved the way to study DNA methylation on a genome-wide scale, DNA methylation studies cannot rely on non-specific methods, as they cannot be directed, they impact too many interconnected pathways, and cannot lead to accurate outcomes.

Accurate DNA methylation mark induction and removal have complementary functions and could both play a role in crop improvement. DNA hypermethylation is, for example, involved in crop 
stress resistance mechanisms, such as wheat salt tolerance, pea and barley response to drought stress, and tomato response to cold [58-61]. Meanwhile, DNA hypomethylation is implicated in drought stress response in rice and faba beans, and heat response in soybean and rapeseed [62-65].

Site-specific methylome modifications have been made possible with the development of epigenome editing tools. Epigenome editing tools consist of two essential components: a DNA-binding targeting domain and a functional domain. The targeting domain can be based on Zinc finger (ZF) proteins, Transcription activator-like effectors (TALEs) or the Clustered Regularly Interspaced Short Palindromic Repeats (CRISPR-Cas9) system [66]. They can induce epigenetic modifications at a site-specific level, precisely enough to efficiently target promoters, and therefore are valuable tools for precision epigenome engineering.

\subsection{Zinc Finger Proteins}

Zinc finger proteins are DNA-binding motifs naturally present in many transcription factors, and they can be modified to recognize any unique sequence in a genome. Each finger is composed of 30 amino acids, able to recognize a three base pair segment and their association can be engineered to target any specific sequence [67]. ZF proteins represent the first generation of DNA editing tools and have been used for epigenetic modification since 2002 [68]. Their compact size makes them well suited to target highly condensed regions; however, they can be both laborious and expensive to assemble $[66,69]$. ZFs associated with a protein essential to RNA directed DNA methylation (RdDM) were successfully used in A. thaliana for the first time in 2014 to induce methylation. Targeted to an unmethylated epiallele of $F W A$, it resulted in early flowering of the plants, suggesting the silencing of the gene [70].

In the case of induced demethylation, the combination of ZFs with DNA demethylase TET1 can result in the demethylation of methylation sites hundreds of bases away from the target [71]. Incomplete demethylation can be restored quickly to its original fully methylated state by the RNA-directed methylation machinery after the removal of the ZF. It is still unknown if targeted demethylation can be transmitted to offspring [71]. The use of ZF is today limited in epigenome editing because of their lack of binding specificity and thus, wide off-target effects [72].

\subsection{Transcription Activator-like Effector (TALEs)}

Transcription activator-like effectors are proteins secreted by Xanthomonas bacteria that bind to specific gene promoters. TALEs are formed of tandem repeats, which are usually 34 amino acids in length, in which specific amino acids (in position 12 and 13) can target single DNA bases [73]. TALEs are an improvement over ZF proteins, as they show higher specificity, are more convenient to engineer as they do not need an assembly step to build long sequence-specific arrays and they allow more design flexibility due to their single base recognition ability [74]. However, their manipulation is still costly and labor intensive, as they need to be designed specifically for their target, and their large size limits their access to most target sequences. Moreover, interactions with methylated DNA restrict their binding capacity, reducing their potential use for epigenome editing [75]. TALEs are still popular epigenome editing tools, proving their efficacy for gene expression modulation even when compared to the next generation tool CRISPR-Cas9 [76].

\subsection{CRISPR-Cas9}

The CRISPR gene family evolved as part of bacterial and archaeal immune systems, and today it has been co-opted to become the most accessible and affordable gene-editing tool available. The CRISPR-Cas9 system has two components: (i) clustered regularly interspaced short palindromic repeats (CRISPRs), which are short repetitive DNA sequences, and (ii) the endonuclease CRISPR-associated protein 9 (Cas9). In epigenome editing, the endonuclease activity of Cas9 is not required and the use of an inactive version (dCas9) confers to CRISPR the same editing potential as ZF and TALE [77]. Recent innovations have expanded the application of CRISPR technology, 
enabling site-specific induction of DNA methylation [66]. The CRISPR-Cas system requires the presence of a protospacer adjacent motif (PAM), which is a two to six nucleotide long sequence following the targeted region that limits the targeting range of the method. Another weakness of the method is that perfect complementarity between the targeted DNA and the binding domain is not necessary for the binding to occur, enhancing the risk of off-target effects [78].

CRISPR-Cas9 can be used for the purposes of gene silencing when fused to a DNA methyltransferase [79,80], and gene activation when fused with the catalytic domain of TET1 [81,82]. A CRISPR-based system was successfully used in A. thaliana to induce the methylation of the FWA promoter, causing an early flowering phenotype [83]. Several genes in rice that were identified as negative regulators of yield (Gn1a, DEP1, GS3, IPA1) and grain weight (GW2, GW5 and TGW6) were knocked out with CRISPR-Cas9, resulting in increased grain number, size and weight $[84,85]$. Inducing targeted DNA methylation to modify the expression of genes that negatively impact yield could be an effective alternative to gene knockouts, which can have deleterious off-target effects [86]. The main advantage of CRISPR-Cas9 over other gene-editing tools is the ability to use guide RNAs (gRNA) to drive the functional domain with no need to design specific DNA binding proteins. This specificity means that assembling the CRISPR-Cas9 complex and directing it to the site is easier to engineer compared to ZF and TALEs [87]. One other significant advancement is that, unlike ZFs and TALEs, CRISPR-Cas 9 can target and edit multiple genomic sites at once [66]. The use of different RNA-binding domains associated with different Cas9 orthologs enables the targeting of multiple sites simultaneously [88].

\subsection{Perspectives for Plant Breeding}

(Epi)genome editing tools have enabled the application of methylation modification to plant breeding. The first generation tool, ZFs, remain useful due to their small size and binding properties, though TALE-based systems are easier to engineer. TALEs present a problematic sensitivity to DNA methylation, which complicates their use for epigenome editing. The CRISPR-Cas9 system presents comparable efficiency but with easier and cheaper implementation, and the ability to target multiple sites (multiplex) (Table 3). CRISPR-Cas9 is already largely used in genome editing, and is quickly becoming the most popular tool for inducing methylation in plants.

Table 3. Comparison of epigenetic editing tools.

\begin{tabular}{cccccc}
\hline Locus Specific & $\begin{array}{c}\text { Sensitivity to } \\
\text { DNA Methylation }\end{array}$ & $\begin{array}{c}\text { Capacity for } \\
\text { Multiplex }\end{array}$ & $\begin{array}{c}\text { Ease to } \\
\text { Engineer }\end{array}$ & $\begin{array}{c}\text { Potential as } \\
\text { Epigenetic Tool }\end{array}$ \\
\hline Gene KO & no & no & no & Yes & no \\
\hline ZF proteins & yes & no & no & No & yes \\
\hline TALE & yes & yes & no & no & no \\
\hline CRISPR-cas9 & yes & no & yes & yes & yes \\
\hline
\end{tabular}

CRISPR-Cas9 has already been effectively applied to edit a wide range of crop genomes, including rice, potato, sweet orange, soybean, tomato, maize and cotton [89-95]. However, the use of endonucleases runs the risk of inducing off-target double-strand breaks (DSBs) which can lead to unpredictable mutations elsewhere in the genome. Epigenome editing with CRISPR-Cas9 results in less extreme off-target activity than genome editing, as its effects are progressive and proportionate to target binding. Moreover, most off-target effects will occur in non-regulatory regions, making them silent [86]. In addition, epigenetic mutagenesis can lead to a genetic gain of function, as opposed to most genetic variants, which tend to cause a loss of function [96].

Epigenome editing could be beneficial to plant breeding at several levels. Firstly, as with genetic modifications, it could accelerate the process of domestication of wild plants through the modification of traits involved in growth habit, flowering time, yield, nutrition, as well as seed and fruit size and 
number, in a single generation. However, in contrast to gene knockout, induced (de)methylation has an adjustable impact and can influence both gene expression and repression. Induced DNA methylation could also improve hybrid breeding and plant propagation through tissue-culture, which can induce new gene expression patterns in their progeny $[4,5,97,98]$, and thus help control offspring phenotype. It could be used to eliminate deleterious traits or add desired characteristics to crops, such as biotic and abiotic stress resistance (Table 1). Finally, it could induce plant resistance to viruses or even alter a pathogen population, making it susceptible to the plant's defenses [99].

\section{Limitations}

Several limitations hinder the widespread use of induced DNA methylation in plant breeding. First at a biological level, with the determination of genes to target, the durable maintenance of induced epialleles and the presence of off-target effects. Second, the introduction of inappropriate legislation regarding new breeding techniques that restrict research and the implementation of advanced breeding approaches.

\subsection{Biological Limitations}

DNA methylation often plays an important role in controlling gene expression. However, DNA methylation is part of a complex regulatory system and so its alteration is not always sufficient to impact gene transcription. Therefore, the modification of crop DNA methylation patterns should be supported by other transcriptional regulators such as chromatin markers, which is an area of research yet to be fully explored [100,101].

The short term heritability of DNA methylation pattern in plants has been largely demonstrated in different species (Table 2). However, as growing successive generations of plants can be laborious and time-consuming, most studies are limited to only a few generations, thus the long-term methylation pattern heritability remains largely unstudied. Moreover, the maintenance of induced methylation is uncertain, and a recent mammalian study revealed that removal of the methylation induction system led to a restoration of natural transcriptional levels [102].

\subsection{Technology Limitations}

CRISPR-cas9 is the most promising epigenome editing tool to date. However, its main drawback is the presence of off-target activity. A study testing CRISPR-Cas9 specificity when applied to the human genome showed that $98.4 \%$ of the tested guide RNAs designed to target exons had at least one off-target site [103]. Off-target binding seems inevitable in large genomes; however, different methods exist to improve CRISPR-Cas9 specificity. Novel machine learning algorithms enable the efficient design of sgRNAs, based on experimentally validated examples [104-106]. Limiting the amount of both Cas9 and sgRNA could minimize off-target modifications, as higher concentrations of these increase the risk of binding to sites containing mismatches [107,108]. Engineered Cas9 variants can increase CRISPR-Cas9 specificity by decreasing its tolerance to mismatches when binding to DNA [109]. Finally, some Cas9 orthologs could have advantages over the commonly used wild type SpCas9, such as greater specificity, which could be another way to reduce off-target effects [88].

\subsection{Legislation}

Numerous Genetically Modified Organism (GMO) regulations are based on obsolete definitions which do not include new plant breeding techniques and are not suitable for contemporary methods for altering genomes. In July 2018, the European Court of Justice decided that plants issued from genomic editing processes, even those not involving the use of recombinant DNA, fall under current GMO regulation [110]. In contrast, some countries, such as Canada, define the safety of new crops based on the properties of the final product (product-based) rather than the technique used to produce it (process-based). The United States adopted a hybrid system in which only plants presenting new traits fall under specific regulations [111]. In 2019, the Australian government ended regulation of 
"DNA free" gene-editing techniques. The amendment of regulations regarding new plant breeding techniques is important, as both scientific and economic benefits depend upon it [112].

The difficulty associated with distinguishing between organisms presenting random natural mutations and those that have undergone new plant breeding techniques presents a significant obstacle to updating obsolete legislation [111]. The gap that exists between scientific knowledge regarding the impact of new plant breeding techniques on human and environmental health with the current legislation is a major bottleneck of the expansion of (epi)genome-edited crops [113].

\section{Conclusions}

Improved understanding of the implication of epigenetics on phenotype has led to an increase in the number of epigenome studies, revealing the plurality and complexity of the mechanisms involved in methylation. DNA methylation appears to have played a significant role in plant domestication and evolution, and therefore has the potential to be used as a powerful tool to improve crop agronomic traits, such as yield and disease resistance. Modification of the crop methylome through induced methylation and the regulation of crop gene expression will allow breeders to maximize the genetic potential naturally present in the plants far quicker than through traditional breeding. It appears as complementary to genome editing, with (i) an adaptable impact, (ii) the potential to reveal hidden phenotypic variations and (iii) a reduced off-target effect. For these reasons, the modulation of crop DNA methylation pattern is considered to have significant potential in breeding, and updated regulations should support its expansion. The stable transmission of epialleles involved in agronomically important traits across generations is essential for the inclusion of epigenetic variations in breeding programs. CRISPR-Cas9 is the most powerful genome-editing tool created so far and we have just started exploring its full potential. Nevertheless, in order to fully incorporate targeted DNA methylation into the breeding process, challenges such as precise genomic target identification, durable maintenance of induced epialleles, control of off-target effects, and revision of current legislation must be addressed.

Author Contributions: C.M., P.E.B., C.T.F., J.B. and D.E. wrote, reviewed and edited the manuscript. All authors have read and agree to the published version of the manuscript.

Funding: This work is funded by the Australia Research Council (Projects LP130100061, DP1601004497, LP160100030 and DP200100762). Dr. Philipp Bayer acknowledges the support of the Forrest Research Foundation.

Conflicts of Interest: The authors declare no conflict of interest

\section{References}

1. Song, Q.; Zhang, T.; Stelly, D.M.; Chen, Z.J. Epigenomic and functional analyses reveal roles of epialleles in the loss of photoperiod sensitivity during domestication of allotetraploid cottons. Genome Biol. 2017, 18, 99. [CrossRef] [PubMed]

2. Zhang, Y.-Y.; Fischer, M.; Colot, V.; Bossdorf, O. Epigenetic variation creates potential for evolution of plant phenotypic plasticity. New Phytol. 2013, 197, 314-322. [CrossRef] [PubMed]

3. Liu, B.; Wendel, J.F. Epigenetic phenomena and the evolution of plant allopolyploids. Mol. Phylogenet. Evol. 2003, 29, 365-379. [CrossRef] [PubMed]

4. Stroud, H.; Ding, B.; Simon, S.A.; Feng, S.; Bellizzi, M.; Pellegrini, M.; Wang, G.-L.; Meyers, B.C.; Jacobsen, S.E. Plants regenerated from tissue culture contain stable epigenome changes in rice. eLife 2013, 2, e00354. [CrossRef] [PubMed]

5. Stelpflug, S.C.; Eichten, S.R.; Hermanson, P.J.; Springer, N.M.; Kaeppler, S.M. Consistent and heritable alterations of DNA methylation are induced by tissue culture in maize. Genetics 2014, 198, 209-218. [CrossRef] [PubMed]

6. Lin, W.; Xiao, X.; Zhang, H.; Li, Y.; Liu, S.; Sun, W.; Zhang, X.; Wu, Q. Whole-Genome Bisulfite Sequencing Reveals a Role for DNA Methylation in Variants from Callus Culture of Pineapple (Ananas comosus L.). Genes 2019, 10, 877. [CrossRef] 
7. Zhang, D.; Wang, Z.; Wang, N.; Gao, Y.; Liu, Y.; Wu, Y.; Bai, Y.; Zhang, Z.; Lin, X.; Dong, Y.; et al. Tissue culture-induced heritable genomic variation in rice, and their phenotypic implications. PLoS ONE 2014, 9, e96879. [CrossRef]

8. Han, Z.; Crisp, P.A.; Stelpflug, S.; Kaeppler, S.M.; Li, Q.; Springer, N.M. Heritable Epigenomic Changes to the Maize Methylome Resulting from Tissue Culture. Genetics 2018, 209, 983-995. [CrossRef]

9. Bestor, T.H. DNA methylation: Evolution of a bacterial immune function into a regulator of gene expression and genome structure in higher eukaryotes. Philos. Trans. R. Soc. Lond. B Biol. Sci. 1990, 326, 179-187. [CrossRef]

10. Miura, A.; Yonebayashi, S.; Watanabe, K.; Toyama, T.; Shimada, H.; Kakutani, T. Mobilization of transposons by a mutation abolishing full DNA methylation in Arabidopsis. Nature 2001, 411, 212-214. [CrossRef]

11. Sekhon, R.S.; Peterson, T.; Chopra, S. Epigenetic modifications of distinct sequences of the p1 regulatory gene specify tissue-specific expression patterns in maize. Genetics 2007, 175, 1059-1070. [CrossRef] [PubMed]

12. Zhang, M.; Xu, C.; von Wettstein, D.; Liu, B. Tissue-specific differences in cytosine methylation and their association with differential gene expression in sorghum. Plant Physiol. 2011, 156, 1955-1966. [CrossRef] [PubMed]

13. Lee, H.S.; Chen, Z.J. Protein-coding genes are epigenetically regulated in Arabidopsis polyploids. Proc. Natl. Acad. Sci. USA 2001, 98, 6753-6758. [CrossRef] [PubMed]

14. Wang, J.; Tian, L.; Madlung, A.; Lee, H.-S.; Chen, M.; Lee, J.J.; Watson, B.; Kagochi, T.; Comai, L.; Chen, Z.J. Stochastic and epigenetic changes of gene expression in Arabidopsis polyploids. Genetics 2004, 167, 1961-1973. [CrossRef]

15. Holliday, R.; Pugh, J.E. DNA modification mechanisms and gene activity during development. Science 1975, 187, 226-232. [CrossRef]

16. Riggs, A.D. X inactivation, differentiation, and DNA methylation. Cytogenet. Cell Genet. 1975, 14, 9-25. [CrossRef]

17. Lang, Z.; Wang, Y.; Tang, K.; Tang, D.; Datsenka, T.; Cheng, J.; Zhang, Y.; Handa, A.K.; Zhu, J.-K. Critical roles of DNA demethylation in the activation of ripening-induced genes and inhibition of ripening-repressed genes in tomato fruit. Proc. Natl. Acad. Sci. USA 2017, 114, E4511-E4519. [CrossRef]

18. Srikant, T.; Wibowo, A.; Schwab, R.; Weigel, D. Position-dependent effects of cytosine methylation on FWA expression in Arabidopsis thaliana. BioRxiv 2019, 774281. [CrossRef]

19. Zubko, E.; Gentry, M.; Kunova, A.; Meyer, P. De novo DNA methylation activity of methyltransferase 1 (MET1) partially restores body methylation in Arabidopsis thaliana. Plant J. 2012, 71, 1029-1037. [CrossRef]

20. Takuno, S.; Gaut, B.S. Body-methylated genes in Arabidopsis thaliana are functionally important and evolve slowly. Mol. Biol. Evol. 2012, 29, 219-227. [CrossRef]

21. Regulski, M.; Lu, Z.; Kendall, J.; Donoghue, M.T.A.; Reinders, J.; Llaca, V.; Deschamps, S.; Smith, A.; Levy, D.; McCombie, W.R.; et al. The maize methylome influences mRNA splice sites and reveals widespread paramutation-like switches guided by small RNA. Genome Res. 2013, 23, 1651-1662. [CrossRef] [PubMed]

22. Zilberman, D.; Gehring, M.; Tran, R.K.; Ballinger, T.; Henikoff, S. Genome-wide analysis of Arabidopsis thaliana DNA methylation uncovers an interdependence between methylation and transcription. Nat. Genet. 2007, 39, 61-69. [CrossRef] [PubMed]

23. Cubas, P.; Vincent, C.; Coen, E. An epigenetic mutation responsible for natural variation in floral symmetry. Nature 1999, 401, 157-161. [CrossRef] [PubMed]

24. Manning, K.; Tör, M.; Poole, M.; Hong, Y.; Thompson, A.J.; King, G.J.; Giovannoni, J.J.; Seymour, G.B. A naturally occurring epigenetic mutation in a gene encoding an SBP-box transcription factor inhibits tomato fruit ripening. Nat. Genet. 2006, 38, 948-952. [CrossRef] [PubMed]

25. Johannes, F.; Porcher, E.; Teixeira, F.K.; Saliba-Colombani, V.; Simon, M.; Agier, N.; Bulski, A.; Albuisson, J.; Heredia, F.; Audigier, P.; et al. Assessing the impact of transgenerational epigenetic variation on complex traits. PLoS Genet. 2009, 5, e1000530. [CrossRef] [PubMed]

26. Jiang, C.; Mithani, A.; Belfield, E.J.; Mott, R.; Hurst, L.D.; Harberd, N.P. Environmentally responsive genome-wide accumulation of de novo Arabidopsis thaliana mutations and epimutations. Genome Res. 2014, 24, 1821-1829. [CrossRef] [PubMed]

27. Gao, L.; Geng, Y.; Li, B.; Chen, J.; Yang, J. Genome-wide DNA methylation alterations of Alternanthera philoxeroides in natural and manipulated habitats: Implications for epigenetic regulation of rapid responses to environmental fluctuation and phenotypic variation. Plant Cell Environ. 2010, 33, 1820-1827. [CrossRef] 
28. Gourcilleau, D.; Mousset, M.; Latutrie, M.; Marin, S.; Delaunay, A.; Maury, S.; Pujol, B. Assessing Global DNA Methylation Changes Associated with Plasticity in Seven Highly Inbred Lines of Snapdragon Plants (Antirrhinum majus). Genes 2019, 10, 256. [CrossRef]

29. Schmid, M.W.; Heichinger, C.; Coman Schmid, D.; Guthörl, D.; Gagliardini, V.; Bruggmann, R.; Aluri, S.; Aquino, C.; Schmid, B.; Turnbull, L.A.; et al. Contribution of epigenetic variation to adaptation in Arabidopsis. Nat. Commun. 2018, 9, 4446. [CrossRef]

30. Aina, R.; Sgorbati, S.; Santagostino, A.; Labra, M.; Ghiani, A.; Citterio, S. Specific hypomethylation of DNA is induced by heavy metals in white clover and industrial hemp. Physiol. Plant. 2004, 121, 472-480. [CrossRef]

31. Tang, X.; Wang, Q.; Yuan, H.; Huang, X. Chilling-induced DNA Demethylation is associated with the cold tolerance of Hevea brasiliensis. BMC Plant Biol. 2018, 18, 70. [CrossRef] [PubMed]

32. Dyachenko, O.V.; Zakharchenko, N.S.; Shevchuk, T.V.; Bohnert, H.J.; Cushman, J.C.; Buryanov, Y.I. Effect of hypermethylation of CCWGG sequences in DNA of Mesembryanthemum crystallinum plants on their adaptation to salt stress. Biochem. Mosc. 2006, 71, 461-465. [CrossRef] [PubMed]

33. Wada, Y.; Miyamoto, K.; Kusano, T.; Sano, H. Association between up-regulation of stress-responsive genes and hypomethylation of genomic DNA in tobacco plants. Mol. Genet. Genom. 2004, 271, 658-666. [CrossRef] [PubMed]

34. Choi, C.-S.; Sano, H. Abiotic-stress induces demethylation and transcriptional activation of a gene encoding a glycerophosphodiesterase-like protein in tobacco plants. Mol. Genet. Genom. 2007, 277, 589-600. [CrossRef]

35. Quadrana, L.; Almeida, J.; Asís, R.; Duffy, T.; Dominguez, P.G.; Bermúdez, L.; Conti, G.; da Silva, J.V.C.; Peralta, I.E.; Colot, V.; et al. Natural occurring epialleles determine vitamin E accumulation in tomato fruits. Nat. Commun. 2014, 5, 4027. [CrossRef]

36. Steward, N.; Ito, M.; Yamaguchi, Y.; Koizumi, N.; Sano, H. Periodic DNA methylation in maize nucleosomes and demethylation by environmental stress. J. Biol. Chem. 2002, 277, 37741-37746. [CrossRef]

37. Tani, E.; Polidoros, A.N.; Nianiou-Obeidat, I.; Tsaftaris, A.S. DNA methylation patterns are differently affected by planting density in maize inbreds and their hybrids. Maydica 2005, 50, 19.

38. van der Graaf, A.; Wardenaar, R.; Neumann, D.A.; Taudt, A.; Shaw, R.G.; Jansen, R.C.; Schmitz, R.J.; Colomé-Tatché, M.; Johannes, F. Rate, spectrum, and evolutionary dynamics of spontaneous epimutations. Proc. Natl. Acad. Sci. USA 2015, 112, 6676-6681. [CrossRef]

39. Zheng, X.; Chen, L.; Xia, H.; Wei, H.; Lou, Q.; Li, M.; Li, T.; Luo, L. Transgenerational epimutations induced by multi-generation drought imposition mediate rice plant's adaptation to drought condition. Sci. Rep. 2017, 7, 39843. [CrossRef]

40. Yong-Villalobos, L.; González-Morales, S.I.; Wrobel, K.; Gutiérrez-Alanis, D.; Cervantes-Peréz, S.A.; Hayano-Kanashiro, C.; Oropeza-Aburto, A.; Cruz-Ramírez, A.; Martínez, O.; Herrera-Estrella, L. Methylome analysis reveals an important role for epigenetic changes in the regulation of the Arabidopsis response to phosphate starvation. Proc. Natl. Acad. Sci. USA 2015, 112, E7293-E7302. [CrossRef]

41. Dowen, R.H.; Pelizzola, M.; Schmitz, R.J.; Lister, R.; Dowen, J.M.; Nery, J.R.; Dixon, J.E.; Ecker, J.R. Widespread dynamic DNA methylation in response to biotic stress. Proc. Natl. Acad. Sci. USA 2012, 109, E2183-E2191. [CrossRef] [PubMed]

42. Feng, S.J.; Liu, X.S.; Tao, H.; Tan, S.K.; Chu, S.S.; Oono, Y.; Zhang, X.D.; Chen, J.; Yang, Z.M. Variation of DNA methylation patterns associated with gene expression in rice (Oryza sativa) exposed to cadmium. Plant Cell Environ. 2016, 39, 2629-2649. [CrossRef] [PubMed]

43. Narsai, R.; Secco, D.; Schultz, M.D.; Ecker, J.R.; Lister, R.; Whelan, J. Dynamic and rapid changes in the transcriptome and epigenome during germination and in developing rice (Oryza sativa) coleoptiles under anoxia and re-oxygenation. Plant J. 2017, 89, 805-824. [CrossRef] [PubMed]

44. Wang, W.-S.; Pan, Y.-J.; Zhao, X.-Q.; Dwivedi, D.; Zhu, L.-H.; Ali, J.; Fu, B.-Y.; Li, Z.-K. Drought-induced site-specific DNA methylation and its association with drought tolerance in rice (Oryza sativa L.). J. Exp. Bot. 2011, 62, 1951-1960. [CrossRef] [PubMed]

45. Hagmann, J.; Becker, C.; Müller, J.; Stegle, O.; Meyer, R.C.; Wang, G.; Schneeberger, K.; Fitz, J.; Altmann, T.; Bergelson, J.; et al. Century-scale methylome stability in a recently diverged Arabidopsis thaliana lineage. PLoS Genet. 2015, 11, e1004920. [CrossRef] [PubMed]

46. Secco, D.; Wang, C.; Shou, H.; Schultz, M.D.; Chiarenza, S.; Nussaume, L.; Ecker, J.R.; Whelan, J.; Lister, R. Stress induced gene expression drives transient DNA methylation changes at adjacent repetitive elements. eLife 2015, 4, e09343. [CrossRef] [PubMed] 
47. Whittle, C.A.; Otto, S.P.; Johnston, M.O.; Krochko, J.E. Adaptive epigenetic memory of ancestral temperature regime in Arabidopsis thaliana. Botany 2009, 87, 650-657. [CrossRef]

48. Johnsen, O.; Daehlen, O.G.; Ostreng, G.; Skrøppa, T. Daylength and temperature during seed production interactively affect adaptive performance of Picea abies progenies. New Phytol. 2005, 168, 589-596. [CrossRef] [PubMed]

49. Verhoeven, K.J.F.; Jansen, J.J.; van Dijk, P.J.; Biere, A. Stress-induced DNA methylation changes and their heritability in asexual dandelions. New Phytol. 2010, 185, 1108-1118. [CrossRef]

50. Kathiria, P.; Sidler, C.; Golubov, A.; Kalischuk, M.; Kawchuk, L.M.; Kovalchuk, I. Tobacco mosaic virus infection results in an increase in recombination frequency and resistance to viral, bacterial, and fungal pathogens in the progeny of infected tobacco plants. Plant Physiol. 2010, 153, 1859-1870. [CrossRef]

51. Kou, H.P.; Li, Y.; Song, X.X.; Ou, X.F.; Xing, S.C.; Ma, J.; Von Wettstein, D.; Liu, B. Heritable alteration in DNA methylation induced by nitrogen-deficiency stress accompanies enhanced tolerance by progenies to the stress in rice (Oryza sativa L.). J. Plant Physiol. 2011, 168, 1685-1693. [CrossRef] [PubMed]

52. Wang, X.; Xin, C.; Cai, J.; Zhou, Q.; Dai, T.; Cao, W.; Jiang, D. Heat Priming Induces Trans-generational Tolerance to High Temperature Stress in Wheat. Front. Plant Sci. 2016, 7, 501. [CrossRef] [PubMed]

53. Herman, J.J.; Sultan, S.E. DNA methylation mediates genetic variation for adaptive transgenerational plasticity. Proc. Biol. Sci. 2016, 283, 20160988. [CrossRef] [PubMed]

54. Stassen, J.H.M.; López, A.; Jain, R.; Pascual-Pardo, D.; Luna, E.; Smith, L.M.; Ton, J. The relationship between transgenerational acquired resistance and global DNA methylation in Arabidopsis. Sci. Rep. 2018, 8, 14761. [CrossRef]

55. Cong, W.; Miao, Y.; Xu, L.; Zhang, Y.; Yuan, C.; Wang, J.; Zhuang, T.; Lin, X.; Jiang, L.; Wang, N.; et al. Transgenerational memory of gene expression changes induced by heavy metal stress in rice (Oryza sativa L.). BMC Plant Biol. 2019, 19, 282. [CrossRef]

56. Akimoto, K.; Katakami, H.; Kim, H.-J.; Ogawa, E.; Sano, C.M.; Wada, Y.; Sano, H. Epigenetic inheritance in rice plants. Ann. Bot. 2007, 100, 205-217. [CrossRef]

57. Finnegan, E.J.; Peacock, W.J.; Dennis, E.S. Reduced DNA methylation in Arabidopsis thaliana results in abnormal plant development. Proc. Natl. Acad. Sci. USA 1996, 93, 8449-8454. [CrossRef] [PubMed]

58. Kumar, S.; Beena, A.S.; Awana, M.; Singh, A. Physiological, Biochemical, Epigenetic and Molecular Analyses of Wheat (Triticum aestivum) Genotypes with Contrasting Salt Tolerance. Front. Plant Sci. 2017, 8, 1151. [CrossRef]

59. Labra, M.; Ghiani, A.; Citterio, S.; Sgorbati, S.; Sala, F.; Vannini, C.; Ruffini-Castiglione, M.; Bracale, M. Analysis of cytosine methylation pattern in response to water deficit in pea root tips. Plant Biol. 2002, 4, 694-699. [CrossRef]

60. Surdonja, K.; Eggert, K.; Hajirezaei, M.-R.; Harshavardhan, V.; Seiler, C.; von Wirén, N.; Sreenivasulu, N.; Kuhlmann, M. Increase of DNA methylation at the hvckx2.1 promoter by terminal drought stress in barley. Epigenomes 2017, 1, 9. [CrossRef]

61. Zhang, B.; Tieman, D.M.; Jiao, C.; Xu, Y.; Chen, K.; Fei, Z.; Giovannoni, J.J.; Klee, H.J. Chilling-induced tomato flavor loss is associated with altered volatile synthesis and transient changes in DNA methylation. Proc. Natl. Acad. Sci. USA 2016, 113, 12580-12585. [CrossRef] [PubMed]

62. Joel, A.J. Epigenetic responses to drought stress in rice (Oryza sativa L.). Physiol. Mol. Biol. Plants 2013, 19, 379-387. [CrossRef]

63. Abid, G.; Mingeot, D.; Muhovski, Y.; Mergeai, G.; Aouida, M.; Abdelkarim, S.; Aroua, I.; El Ayed, M.; M'hamdi, M.; Sassi, K.; et al. Analysis of DNA methylation patterns associated with drought stress response in faba bean (Vicia faba L.) using methylation-sensitive amplification polymorphism (MSAP). Environ. Exp. Bot. 2017, 142, 34-44. [CrossRef]

64. Hossain, M.S.; Kawakatsu, T.; Kim, K.D.; Zhang, N.; Nguyen, C.T.; Khan, S.M.; Batek, J.M.; Joshi, T.; Schmutz, J.; Grimwood, J.; et al. Divergent cytosine DNA methylation patterns in single-cell, soybean root hairs. New Phytol. 2017, 214, 808-819. [CrossRef] [PubMed]

65. Gao, G.; Li, J.; Li, H.; Li, F.; Xu, K.; Yan, G.; Chen, B.; Qiao, J.; Wu, X. Comparison of the heat stress induced variations in DNA methylation between heat-tolerant and heat-sensitive rapeseed seedlings. Breed. Sci. 2014, 64, 125-133. [CrossRef] 
66. Vojta, A.; Dobrinić, P.; Tadić, V.; Bočkor, L.; Korać, P.; Julg, B.; Klasić, M.; Zoldoš, V. Repurposing the CRISPR-Cas9 system for targeted DNA methylation. Nucleic Acids Res. 2016, 44, 5615-5628. [CrossRef] [PubMed]

67. Sera, T.; Uranga, C. Rational design of artificial zinc-finger proteins using a nondegenerate recognition code table. Biochemistry 2002, 41, 7074-7081. [CrossRef]

68. Snowden, A.W.; Gregory, P.D.; Case, C.C.; Pabo, C.O. Gene-specific targeting of H3K9 methylation is sufficient for initiating repression in vivo. Curr. Biol. 2002, 12, 2159-2166. [CrossRef]

69. Cano-Rodriguez, D.; Rots, M.G. Epigenetic editing: On the verge of reprogramming gene expression at will. Curr. Genet. Med. Rep. 2016, 4, 170-179. [CrossRef]

70. Johnson, L.M.; Du, J.; Hale, C.J.; Bischof, S.; Feng, S.; Chodavarapu, R.K.; Zhong, X.; Marson, G.; Pellegrini, M.; Segal, D.J.; et al. SRA- and SET-domain-containing proteins link RNA polymerase V occupancy to DNA methylation. Nature 2014, 507, 124-128. [CrossRef]

71. Gallego-Bartolomé, J.; Gardiner, J.; Liu, W.; Papikian, A.; Ghoshal, B.; Kuo, H.Y.; Zhao, J.M.-C.; Segal, D.J.; Jacobsen, S.E. Targeted DNA demethylation of the Arabidopsis genome using the human TET1 catalytic domain. Proc. Natl. Acad. Sci. USA 2018, 115, E2125-E2134. [CrossRef] [PubMed]

72. Grimmer, M.R.; Stolzenburg, S.; Ford, E.; Lister, R.; Blancafort, P.; Farnham, P.J. Analysis of an artificial zinc finger epigenetic modulator: Widespread binding but limited regulation. Nucleic Acids Res. 2014, 42, 10856-10868. [CrossRef]

73. Mak, A.N.-S.; Bradley, P.; Bogdanove, A.J.; Stoddard, B.L. TAL effectors: Function, structure, engineering and applications. Curr. Opin. Struct. Biol. 2013, 23, 93-99. [CrossRef] [PubMed]

74. Cermak, T.; Doyle, E.L.; Christian, M.; Wang, L.; Zhang, Y.; Schmidt, C.; Baller, J.A.; Somia, N.V.; Bogdanove, A.J.; Voytas, D.F. Efficient design and assembly of custom TALEN and other TAL effector-based constructs for DNA targeting. Nucleic Acids Res. 2011, 39, e82. [CrossRef]

75. Kaya, H.; Numa, H.; Nishizawa-Yokoi, A.; Toki, S.; Habu, Y. DNA Methylation Affects the Efficiency of Transcription Activator-Like Effector Nucleases-Mediated Genome Editing in Rice. Front. Plant Sci. 2017, 8, 302. [CrossRef] [PubMed]

76. Gao, X.; Tsang, J.C.H.; Gaba, F.; Wu, D.; Lu, L.; Liu, P. Comparison of TALE designer transcription factors and the CRISPR/dCas9 in regulation of gene expression by targeting enhancers. Nucleic Acids Res. 2014, 42, e155. [CrossRef] [PubMed]

77. Qi, L.S.; Larson, M.H.; Gilbert, L.A.; Doudna, J.A.; Weissman, J.S.; Arkin, A.P.; Lim, W.A. Repurposing CRISPR as an RNA-guided platform for sequence-specific control of gene expression. Cell 2013, 152, 1173-1183. [CrossRef]

78. Mali, P.; Aach, J.; Stranges, P.B.; Esvelt, K.M.; Moosburner, M.; Kosuri, S.; Yang, L.; Church, G.M. CAS9 transcriptional activators for target specificity screening and paired nickases for cooperative genome engineering. Nat. Biotechnol. 2013, 31, 833-838. [CrossRef]

79. Xiong, T.; Meister, G.E.; Workman, R.E.; Kato, N.C.; Spellberg, M.J.; Turker, F.; Timp, W.; Ostermeier, M.; Novina, C.D. Targeted DNA methylation in human cells using engineered dCas9-methyltransferases. Sci. Rep. 2017, 7, 6732. [CrossRef]

80. McDonald, J.I.; Celik, H.; Rois, L.E.; Fishberger, G.; Fowler, T.; Rees, R.; Kramer, A.; Martens, A.; Edwards, J.R.; Challen, G.A. Reprogrammable CRISPR/Cas9-based system for inducing site-specific DNA methylation. Biol. Open 2016, 5, 866-874. [CrossRef]

81. Xu, X.; Tao, Y.; Gao, X.; Zhang, L.; Li, X.; Zou, W.; Ruan, K.; Wang, F.; Xu, G.-L.; Hu, R. A CRISPR-based approach for targeted DNA demethylation. Cell Discov. 2016, 2, 16009. [CrossRef] [PubMed]

82. Choudhury, S.R.; Cui, Y.; Lubecka, K.; Stefanska, B.; Irudayaraj, J. CRISPR-dCas9 mediated TET1 targeting for selective DNA demethylation at BRCA1 promoter. Oncotarget 2016, 7, 46545-46556. [CrossRef] [PubMed]

83. Papikian, A.; Liu, W.; Gallego-Bartolomé, J.; Jacobsen, S.E. Site-specific manipulation of Arabidopsis loci using CRISPR-Cas9 SunTag systems. Nat. Commun. 2019, 10, 729. [CrossRef]

84. Li, M.; Li, X.; Zhou, Z.; Wu, P.; Fang, M.; Pan, X.; Lin, Q.; Luo, W.; Wu, G.; Li, H. Reassessment of the Four Yield-related Genes Gn1a, DEP1, GS3, and IPA1 in Rice Using a CRISPR/Cas9 System. Front. Plant Sci. 2016, 7, 377. [CrossRef] [PubMed]

85. Xu, R.; Yang, Y.; Qin, R.; Li, H.; Qiu, C.; Li, L.; Wei, P.; Yang, J. Rapid improvement of grain weight via highly efficient CRISPR/Cas9-mediated multiplex genome editing in rice. J. Genet. Genom. 2016, 43, 529-532. [CrossRef] [PubMed] 
86. Mlambo, T.; Nitsch, S.; Hildenbeutel, M.; Romito, M.; Müller, M.; Bossen, C.; Diederichs, S.; Cornu, T.I.; Cathomen, T.; Mussolino, C. Designer epigenome modifiers enable robust and sustained gene silencing in clinically relevant human cells. Nucleic Acids Res. 2018, 46, 4456-4468. [CrossRef] [PubMed]

87. Kim, M.-S.; Kini, A.G. Engineering and application of zinc finger proteins and tales for biomedical research. Mol. Cells 2017, 40, 533-541. [CrossRef]

88. Steinert, J.; Schiml, S.; Fauser, F.; Puchta, H. Highly efficient heritable plant genome engineering using Cas9 orthologues from Streptococcus thermophilus and Staphylococcus aureus. Plant J. 2015, 84, 1295-1305. [CrossRef]

89. Xu, R.; Li, H.; Qin, R.; Wang, L.; Li, L.; Wei, P.; Yang, J. Gene targeting using the Agrobacterium tumefaciens-mediated CRISPR-Cas system in rice. Rice 2014, 7, 5. [CrossRef]

90. Wang, S.; Zhang, S.; Wang, W.; Xiong, X.; Meng, F.; Cui, X. Efficient targeted mutagenesis in potato by the CRISPR/Cas9 system. Plant Cell Rep. 2015, 34, 1473-1476. [CrossRef]

91. Jia, H.; Wang, N. Targeted genome editing of sweet orange using Cas9/sgRNA. PLoS ONE 2014, 9, e93806. [CrossRef] [PubMed]

92. Cai, Y.; Chen, L.; Liu, X.; Sun, S.; Wu, C.; Jiang, B.; Han, T.; Hou, W. CRISPR/Cas9-Mediated Genome Editing in Soybean Hairy Roots. PLoS ONE 2015, 10, e0136064. [CrossRef]

93. Brooks, C.; Nekrasov, V.; Lippman, Z.B.; Van Eck, J. Efficient gene editing in tomato in the first generation using the clustered regularly interspaced short palindromic repeats/CRISPR-associated9 system. Plant Physiol. 2014, 166, 1292-1297. [CrossRef] [PubMed]

94. Liang, Z.; Zhang, K.; Chen, K.; Gao, C. Targeted mutagenesis in Zea mays using TALENs and the CRISPR/Cas system. J. Genet. Genom. 2014, 41, 63-68. [CrossRef] [PubMed]

95. Chen, X.; Lu, X.; Shu, N.; Wang, S.; Wang, J.; Wang, D.; Guo, L.; Ye, W. Targeted mutagenesis in cotton (Gossypium hirsutum L.) using the CRISPR/Cas9 system. Sci. Rep. 2017, 7, 44304. [CrossRef] [PubMed]

96. Springer, N.M. Epigenetics and crop improvement. Trends Genet. 2013, 29, 241-247. [CrossRef] [PubMed]

97. Hegarty, M.J.; Barker, G.L.; Wilson, I.D.; Abbott, R.J.; Edwards, K.J.; Hiscock, S.J. Transcriptome shock after interspecific hybridization in senecio is ameliorated by genome duplication. Curr. Biol. 2006, 16, 1652-1659. [CrossRef]

98. Buggs, R.J.A.; Zhang, L.; Miles, N.; Tate, J.A.; Gao, L.; Wei, W.; Schnable, P.S.; Barbazuk, W.B.; Soltis, P.S.; Soltis, D.E. Transcriptomic shock generates evolutionary novelty in a newly formed, natural allopolyploid plant. Curr. Biol. 2011, 21, 551-556. [CrossRef] [PubMed]

99. Chen, K.; Wang, Y.; Zhang, R.; Zhang, H.; Gao, C. Crispr/cas genome editing and precision plant breeding in agriculture. Annu. Rev. Plant Biol. 2019, 70, 667-697. [CrossRef]

100. Stepper, P.; Kungulovski, G.; Jurkowska, R.Z.; Chandra, T.; Krueger, F.; Reinhardt, R.; Reik, W.; Jeltsch, A.; Jurkowski, T.P. Efficient targeted DNA methylation with chimeric dCas9-Dnmt3a-Dnmt3L methyltransferase. Nucleic Acids Res. 2017, 45, 1703-1713. [CrossRef]

101. Amabile, A.; Migliara, A.; Capasso, P.; Biffi, M.; Cittaro, D.; Naldini, L.; Lombardo, A. Inheritable Silencing of Endogenous Genes by Hit-and-Run Targeted Epigenetic Editing. Cell 2016, 167, 219-232. [CrossRef] [PubMed]

102. Kungulovski, G.; Nunna, S.; Thomas, M.; Zanger, U.M.; Reinhardt, R.; Jeltsch, A. Targeted epigenome editing of an endogenous locus with chromatin modifiers is not stably maintained. Epigenet. Chromatin 2015, 8, 12. [CrossRef] [PubMed]

103. Bolukbasi, M.F. Development of Chimeric Cas9 Nucleases for Accurate and Flexible Genom. Ph.D. Thesis, University of Massachusetts Medical School, Worcester, MA, USA, 2017.

104. Peng, H.; Zheng, Y.; Zhao, Z.; Liu, T.; Li, J. Recognition of CRISPR/Cas9 off-target sites through ensemble learning of uneven mismatch distributions. Bioinformatics 2018, 34, i757-i765. [CrossRef] [PubMed]

105. Xue, L.; Tang, B.; Chen, W.; Luo, J. Prediction of CRISPR sgRNA Activity Using a Deep Convolutional Neural Network. J. Chem. Inf. Model. 2019, 59, 615-624. [CrossRef]

106. Chuai, G.; Ma, H.; Yan, J.; Chen, M.; Hong, N.; Xue, D.; Zhou, C.; Zhu, C.; Chen, K.; Duan, B.; et al. DeepCRISPR: Optimized CRISPR guide RNA design by deep learning. Genome Biol. 2018, 19, 80. [CrossRef]

107. Hsu, P.D.; Scott, D.A.; Weinstein, J.A.; Ran, F.A.; Konermann, S.; Agarwala, V.; Li, Y.; Fine, E.J.; Wu, X.; Shalem, O; et al. DNA targeting specificity of RNA-guided Cas9 nucleases. Nat. Biotechnol. 2013, 31, 827-832. [CrossRef] 
108. Pattanayak, V.; Lin, S.; Guilinger, J.P.; Ma, E.; Doudna, J.A.; Liu, D.R. High-throughput profiling of off-target DNA cleavage reveals RNA-programmed Cas9 nuclease specificity. Nat. Biotechnol. 2013, 31, 839-843. [CrossRef]

109. Kleinstiver, B.P.; Pattanayak, V.; Prew, M.S.; Tsai, S.Q.; Nguyen, N.T.; Zheng, Z.; Joung, J.K. High-fidelity CRISPR-Cas9 nucleases with no detectable genome-wide off-target effects. Nature 2016, 529, 490-495. [CrossRef]

110. Metje-Sprink, J.; Menz, J.; Modrzejewski, D.; Sprink, T. DNA-Free Genome Editing: Past, Present and Future. Front. Plant Sci. 2018, 9, 1957. [CrossRef]

111. Agapito-Tenfen, S.Z.; Okoli, A.S.; Bernstein, M.J.; Wikmark, O.-G.; Myhr, A.I. Revisiting Risk Governance of GM Plants: The Need to Consider New and Emerging Gene-Editing Techniques. Front. Plant Sci. 2018, 9, 1874. [CrossRef]

112. Davison, J.; Ammann, K. New GMO regulations for old: Determining a new future for EU crop biotechnology. GM Crops Food 2017, 8, 13-34. [CrossRef] [PubMed]

113. Scheben, A.; Edwards, D. Bottlenecks for genome-edited crops on the road from lab to farm. Genome Biol. 2018, 19, 178. [CrossRef] [PubMed]

(C) 2020 by the authors. Licensee MDPI, Basel, Switzerland. This article is an open access article distributed under the terms and conditions of the Creative Commons Attribution (CC BY) license (http://creativecommons.org/licenses/by/4.0/). 